\title{
Antibacterial Activity of Lactic Acid Producing Leuconostoc mesenteroides QZ1178 Against Pathogenic Gallibacterium anatis
}

\begin{abstract}
Hua Zhang ${ }^{1,2,3}$, HePing HuangFu ${ }^{4}$, Xing Wang ${ }^{1,3}$, ShanShan Zhao ${ }^{1,3}$, Yuan Liu ${ }^{1,3}$, Haoxin $L v^{5}$, GuangYong Qin ${ }^{1}$ and Zhongfang $\operatorname{Tan}^{1 *}$

${ }^{1}$ Henan Key Laboratory of Ion-Beam Bioengineering, School of Agricultural Sciences, Zhengzhou University, Zhengzhou, China, ${ }^{2}$ School of Food and Biological Engineering, Henan University of Animal Husbandry and Economy, Zhengzhou, China, ${ }^{3}$ Henan Key Laboratory of lon-Beam Bioengineering, School of Physics and Microelectronics, Zhengzhou University, Zhengzhou, China, ${ }^{4}$ School of Veterinary Medicine, Henan University of Animal Husbandry and Economy, Zhengzhou, China, ${ }^{5}$ School of Food Science and Technology, Henan University of Technology, Zhengzhou, China
\end{abstract}

Lactic acid bacteria ( $\angle A B)$ convert carbohydrates into organic acids [mainly lactic acid (LA)], which reportedly have bactericidal activities. Gallibacterium anatis is a Gram-negative bacteria which infects birds, and causes significant economic losses. In this study, we investigated the antibacterial activity of the LA producing, Leuconostoc mesenteroides QZ1178 from Qula (fermented food), against $G$. anatis, using the Oxford cup method. Our data showed that $L$. mesenteroides QZ1178 inhibited $G$. anatis isolates from different origins; however, L. mesenteroides QZ1178 antibacterial activity dropped dramatically at $\mathrm{pH} 5.5-\mathrm{pH}$ 6. The LA concentration and $\mathrm{pH}$ of the liquid broth containing L. mesenteroides QZ1178 after $24 \mathrm{~h}$ culture was $29 \mathrm{mg} / \mathrm{mL}$ and 3.6, respectively. This concentration $(29 \mathrm{mg} / \mathrm{mL}$ at $\mathrm{pH} 3.6)$ and the antibiotic, cefotaxime (minimum inhibitory concentration (MIC) $2.5 \mu \mathrm{g} / \mathrm{mL}$ ) effectively inhibited $\mathrm{G}$. anatis (GAC026) growth as observed by scanning electron microscopy (SEM) and transmission electron microscopy (TEM). Gallibacterium anatis treated with LA exhibited extensive cell surface collapse, increased cell damage, cell membrane disruption, and cytoplasmic leakage, indicative of cell lysis. We suggest $L$. mesenteroides QZ1178 exerts potential antibacterial effects against the poultry pathogen, $G$. anatis via $L A$.

\footnotetext{
Keywords: poultry pathogens, Gallibacterium anatis, Leuconostoc mesenteroides QZ1178, lactic acid bacteria, multidrug resistance
}

\section{INTRODUCTION}

Lactic acid bacteria (LAB) are used in food preservation, feed fortification, and veterinary medicine $(1,2)$. They exert bacteriostatic effects by interfering with pathogen cell membrane functions, leading to membrane permeability, loss of cell contents, lysis, and death (3-5). Such antimicrobial characteristics are reportedly due to lactic acid (LA) and phenyllactic acid (6-9). Recently, researchers used LAB strains with desirable properties, to modify gut microbiota and target bacterial pathogens (10-15).

Gallibacterium anatis is an opportunistic poultry pathogen residing with the normal microbiota in the respiratory tract and lower genital tract of healthy birds $(16,17)$. Gallibacterium anatis 
may be divided into two biovars: G. anatis haemolytica (GAH) and G. anatis anatis (18). GAH causes salpingitis, peritonitis, and respiratory diseases in chickens, leading to decreased egg production, and increased mortality $(19,20)$. The bacteria was previously isolated from an immunocompromised 26-year-old female with bacteremia and diarrhea, and was speculated to originate from G. anatis contaminated food (21).

Widespread multidrug resistance prevents infection treatments with traditional antibiotics $(22,23)$. As alternatives, $\mathrm{LAB}$ strains have been used to inhibit food-borne pathogens, e.g., cell free supernatants (CFS) from Leuconostoc mesenteroides (from Kimchi) displayed strong antibacterial effects against both Gram-positive and Gram-negative bacteria (24). Similarly, $L$. mesenteroides (from Melichloro cheese) supernatants effectively inhibited Streptococcus pyogenes (25). However, the use of Leuconostoc mesenteroides in inhibiting $G$. anatis has not been reported. In this study, we explored $L$. mesenteroides effects toward G. anatis, and compared them with existing antibiotics to provide mechanistic insights on infection capabilities.

\section{MATERIALS AND METHODS}

\section{Bacterial Strains and Growth Conditions}

Leuconostoc mesenteroides QZ1178 (L. $m$ QZ1178) was previously isolated from Qula, a traditional fermented food from Qinghai Province, China. It was maintained in 25\% (v/v) glycerol stocks at $-80^{\circ} \mathrm{C}$ at Henan Key Laboratory of Ion-Beam Bioengineering, Zhengzhou University. L. mesenteroides QZ1178 was grown in Man Rogosa Sharpe (MRS; Merck, Darmstadt, Germany) solid media at $30^{\circ} \mathrm{C}$ for $48 \mathrm{~h}$. In total, $16 \mathrm{G}$. anatis biovar haemoltica strains were used (Table 1). These strains were isolated, identified and preserved in the clinical veterinary laboratory of Henan University of Animal Husbandry and Economy (26). All G. anatis strains were cultured on blood agar plates (Bosai Zhengzhou, China) containing brain-heart infusion (Oxoid) agar supplemented with 5\% citrated bovine blood in sealed plastic bags at $37^{\circ} \mathrm{C}$.

\section{The Antibacterial Activity of $L$. mesenteroides QZ1178 Against G. anatis}

The antimicrobial activity of $L$. mesenteroides QZ1178 against G. anatis strains was evaluated using the Oxford cup technique (27), with some modification. Briefly, L. mesenteroides QZ1178 was inoculated into MRS broth at $10^{8}$ colony forming units $(\mathrm{CFU}) / \mathrm{mL}$ and static incubated at $30^{\circ} \mathrm{C}$ for $24 \mathrm{~h}$. Cultures were centrifuged at $6,000 \mathrm{rpm}\left(4^{\circ} \mathrm{C}\right)$ for $10 \mathrm{~min}$, with the CFS collected following filtration $(0.22 \mu \mathrm{m}$ membrane). G. anatis (pre-cultured overnight, with an optical density $(\mathrm{OD})=1$ at $600 \mathrm{~nm}$ ) was inoculated onto $5 \mathrm{~mL}$ nutrient agar (NA) $\left(50^{\circ} \mathrm{C}\right)$ using a $3 \%$ inoculant and $5 \%$ citrated bovine blood. After solification, sterilized Oxford cups were pressed lightly onto the NA surface, and dropped into $250 \mu \mathrm{L}$ overnight CFS of L. mesenteroides QZ1178. Inhibition zones were measured after a $24 \mathrm{~h}$ incubation at $37^{\circ} \mathrm{C}$.

\section{Quantification of Organic Acid Production of $L$. mesenteroides QZ1178}

Organic acids, including LA, acetic acid (AA), propionic acid (PA), and butyric acid (BA) were measured using high performance liquid chromatography (HPLC) (Waters 2695 instrument, Waters Co., Ltd., USA; column: Carbomix H-NP10: $8 \%, 7.8 \times 300$ mm, Sepax Technologies, Inc., Delaware, USA; detector: DAD, $214 \mathrm{~nm}$; eluent: $\mathrm{H}_{2} \mathrm{SO}_{4} 2.5 \mathrm{mmol} / \mathrm{L}, 0.6 \mathrm{~mL} / \mathrm{min}$; temperature: $55^{\circ} \mathrm{C}$ ). The $\mathrm{pH}$ was determined using a $\mathrm{pH}$ meter (Mettler Toledo MP230; Greifensee, Switzerland).

\section{Determination of Minimum Inhibitory Concentrations (MIC) for Cefotaxime}

MIC determinations were conducted using the tube dilution method (28). Briefly, cefotaxime (Macklin, Shanghai, China) sodium solution was 2 -fold serially diluted to $1,280,640,320,160$, $80,40,20,10,5,2.5,1.25,0.625 \mu \mathrm{g} / \mathrm{mL}$, and $0 \mu \mathrm{g} / \mathrm{mL}$ in tubes. These were inoculated with $G$. anatis (pre-cultured in MullerHinton broth, final density $=5.0 \times 10^{5} \mathrm{CFU} / \mathrm{mL}$ ) and incubated at $37^{\circ} \mathrm{C}$ for $24 \mathrm{~h}$, followed by optical density measurements using a spectrophotometer (UVmini-1240, SHIMADZU, Japan). Five G. anatis strains from sick chickens from Xinxiang Poultry Hospital were used. As a negative control, blank sterile nutritional broth was used.

\section{Leuconostoc mesenteroides QZ1178 CFS and Cefotaxime Inhibition of $G$. anatis}

Leuconostoc mesenteroides QZ1178 was inoculated into liquid MRS medium at $30^{\circ} \mathrm{C}$ for $24 \mathrm{~h}$. The cell suspension was centrifuged at $6,000 \mathrm{rpm}\left(4^{\circ} \mathrm{C}\right)$ and the supernatant collected. Five G. anatis isolates from chicken palate, cloaca, and fallopian tube were selected as experimental strains. After preculture on solid media, they were inoculated into LB (containing $10 \%$ fetal bovine serum) at $37^{\circ} \mathrm{C}$ at $180 \mathrm{rpm}$ for 8,20 , and $24 \mathrm{~h}$. Gallibacterium anatis strains were then separated into $10 \mathrm{~mL}$ tubes, with each containing $4 \mathrm{~mL}$. L. mesenteroides QZ1178 CFS was then added at 1:1 (high dose) and 1:10 (low dose) ratios, and cefotaxime added at 1:1 (the concentration was referred to MIC). G. anatis strains were cultured for $0,1,3,5$, and $7 \mathrm{~h}$ before viable cell counting. A bacterial culture without treatment was used as a control. Experiments were performed in triplicate.

\section{Leuconostoc mesenteroides QZ1178 CFS and LA Antibacterial Activities Against G. anatis Strains}

Antimicrobial activities were tested at different $\mathrm{pHs}(\mathrm{pH}=4.0$, 5.0, 5.5, and 6) using the Oxford cup method. From HPLC, LA was prepared at $29 \mathrm{mg} / \mathrm{mL}$ and $\mathrm{pH} 3.6$, and also adjusted with $1 \mathrm{M}$ $\mathrm{NaOH}$ to generate different pHs. Approximately $250 \mu \mathrm{L}$ CFS or LA at adjusted pHs were added to the Oxford cups and incubated at $37^{\circ} \mathrm{C}$ for $24 \mathrm{~h}$. Bacterial inhibition zones were measured.

\section{The Inhibitory Effect of Hydrogen Ion on G. anatis}

MRS medium was used to prepare LA, AA, and hydrochloric acid (HA) solutions. From HPLC, LA was prepared at $29 \mathrm{mg} / \mathrm{mL}(\mathrm{pH}$ 
TABLE 1 | Inhibition zones of Leuconostoc mesenteroides QZ1178 CFS against Gallibacterium anatis strains.

\begin{tabular}{|c|c|c|c|}
\hline Gallibacterium anatis & Location & Chicken breed & Inhibition zone (mm) \\
\hline GAC033 (spleen) & Xinxiang poultry disease hospital & Silky blank-bone chicken & ++ \\
\hline GAC034 (liver) & Xinxiang poultry disease hospital & Silky blank-bone chicken & ++ \\
\hline GAC038 (Oviduct) & Xinxiang poultry disease hospital & Silky blank-bone chicken & ++ \\
\hline GAC040 (intestines) & Xinxiang poultry disease hospital & Silky blank-bone chicken & ++ \\
\hline GAC044 (kidneys) & Xinxiang poultry disease hospital & Silky blank-bone chicken & ++ \\
\hline GAC105 (In the cleft palate) & Jinan zhangqiu, shandong province & Lohmann pink laying hen & +++ \\
\hline GAC157 (cloaca) & Shanghai Pudong New Area & Hyline brown laying hen & ++ \\
\hline GAC170 (cloaca) & Jiangxia district, wuhan city, hubei province & Jianghan chicken & ++ \\
\hline GAC171 (In the cleft palate) & Jiangxia district, wuhan city, hubei province & Jianghan chicken & + \\
\hline GAC177 (cloaca) & Jiangxia district, wuhan city, hubei province & Lohmann pink laying hen & ++ \\
\hline GAC021 (In the cleft palate) & Tanghe, nanyang, henan & Silky blank-bone chicken & + \\
\hline GAC032 (Ovary) & Xinxiang poultry disease hospital & Silky blank-bone chicken & + \\
\hline GAC039 (weasand) & Xinxiang poultry disease hospital & Silky blank-bone chicken & + \\
\hline GAC046 (spleen) & Shangqiu zhecheng & Silky blank-bone chicken & + \\
\hline GAC047 (In the cleft palate) & Yangcheng county, jincheng city, Shanxi Province & Hyline brown laying hen & ++ \\
\hline GAC048 (cloaca) & Yangcheng county, jincheng city, Shanxi Province & Hyline brown laying hen & + \\
\hline
\end{tabular}

The inhibition zone is the external diameter of the cup. Diameter of inhibition zone: - , no inhibition; +, 10-15 mm; ++, 15-20 mm; + + +, 20- 25 mm; $n=3$.

TABLE 2 | MIC values and OD values of Cefotaxime antibiotics against five G. anatis (GAC026-GAC030).

\begin{tabular}{|c|c|c|c|c|c|c|c|}
\hline \multirow[t]{2}{*}{ I.D. of Gallibacterium anatis } & \multicolumn{7}{|c|}{ Ceftioxime concentration } \\
\hline & $20 \mu \mathrm{g} / \mathrm{mL}$ & $10 \mu \mathrm{g} / \mathrm{mL}$ & $5 \mu \mathrm{g} / \mathrm{mL}$ & $2.5 \mu \mathrm{g} / \mathrm{mL}$ & $1.25 \mu \mathrm{g} / \mathrm{mL}$ & $0.625 \mu \mathrm{g} / \mathrm{mL}$ & $0 \mu \mathrm{g} / \mathrm{mL}$ \\
\hline GAC026 & $0.10 \pm 0.01^{c}$ & $0.09 \pm 0.00^{c}$ & $0.09 \pm 0.01^{c}$ & $0.09 \pm 0.01^{c}$ & $0.27 \pm 0.01^{b}$ & $0.26 \pm 0.01^{b}$ & $0.30 \pm 0.01^{a}$ \\
\hline GAC027 & $0.07 \pm 0.01^{b}$ & $0.09 \pm 0.01^{b}$ & $0.08 \pm 0.01^{b}$ & $0.11 \pm 0.01^{b}$ & $0.36 \pm 0.02^{a}$ & $0.36 \pm 0.01^{a}$ & $0.37 \pm 0.02^{a}$ \\
\hline GAC028 & $0.01 \pm 0.00^{e}$ & $0.01 \pm 0.00^{e}$ & $0.13 \pm 0.01^{d}$ & $0.23 \pm 0.01^{c}$ & $0.36 \pm 0.02^{b}$ & $0.39 \pm 0.01^{a}$ & $0.41 \pm 0.01^{a}$ \\
\hline GAC029 & $0.10 \pm 0.01^{c}$ & $0.09 \pm 0.01^{c}$ & $0.09 \pm 0.01^{c}$ & $0.37 \pm 0.01^{b}$ & $0.37 \pm 0.01^{b}$ & $0.61 \pm 0.01^{a}$ & $0.59 \pm 0.02^{a}$ \\
\hline GAC030 & $0.01 \pm 0^{f}$ & $0.17 \pm 0.01^{e}$ & $0.25 \pm 0.01^{d}$ & $0.38 \pm 0.01^{c}$ & $0.55 \pm 0.07^{\mathrm{a}}$ & $0.45 \pm 0.01^{b}$ & $0.51 \pm 0.01^{a b}$ \\
\hline
\end{tabular}

Values with different small letters show significant differences in the Ceftioxime concentration treatment $(P<0.05)$.

3.6). AA was prepared at $7 \mathrm{mg} / \mathrm{mL}(\mathrm{pH} 4.5)$. HA at $\mathrm{pH} 3.6$ was also prepared. Organic acid solutions were added to G. anatis cultures at a 1:1 ratio (culture time $=24 \mathrm{~h}$ ). Untreated $G$. anatis cultures were prepared as controls. Cultures were grown at $37^{\circ} \mathrm{C}$ for $0,1,3,5$, and $7 \mathrm{~h}$ before viability measurements. Experiments were performed in triplicate.

\section{Scanning Electron Microscopy (SEM) and Transmission Electron Microscopy (TEM)}

Gallibacterium anatis GAC026 and L. mesenteroides QZ1178 cultures were grown for $24 \mathrm{~h}$ and supernatants collected by centrifugation. LA at $29 \mathrm{mg} / \mathrm{mL}$ was prepared using MRS liquid medium at $\mathrm{pH}$ 3.6. The cefotaxime concentration was set at the MIC. L. mesenteroides QZ1178 CFS, LA, and cefotaxime were added to $G$. anatis cultures at 1:1 ratios, and cells collected at $0,1,3,5$, and $7 \mathrm{~h}$ at $37^{\circ} \mathrm{C}$. Cells were centrifuged at $2,500 \mathrm{rpm}$ for $10 \mathrm{~min}$, washed twice in phosphate-buffered saline $(\mathrm{pH} 7.2)$ and resuspended in $2.5 \%(\mathrm{w} / \mathrm{w})$ glutaraldehyde fixing solution at $4{ }^{\circ} \mathrm{C}$ for $12 \mathrm{~h}$. Cells were dehydrated in $30,50,70,80,90$, and $100 \%$ alcohol for $15 \mathrm{~min}$. After this, they were suspended in $100 \%$ ethanol, fixed on a microslide, and sputter-coated with gold under vacuum. They were then examined by SEM (S4800, HITACHI, Japan). Precipitates were fixed in $4 \%(\mathrm{w} / \mathrm{w})$ glutaraldehyde for $>4 \mathrm{~h}$. Specimens for TEM (JEM-1400, JEOL Ltd., Japan) were prepared by conventional ultrathin sectioning at the TEM Center of Henan University of Chinese Medicine.

\section{Statistical Analysis}

GLM(General linear model) and one-way ANOVA procedures were performed using the SPSS statistical software package (IBM SPSS Statistics; version 20.0; IBM Corporation, Somer, NY, USA). Duncan's multiple comparisons were used to compare differences between groups. Significant differences were accepted at $P<0.05$. CFU variations were plotted using Origin software Pro. 9.0.

\section{RESULTS}

\section{Antimicrobial Activity Using the Oxford Cup Technique}

Based on inhibitory zone results (Table 1), the CFS of $L$. mesenteroides QZ1178 displayed potent antimicrobial activities against all $G$. anatis strains. The antibacterial diameter for 


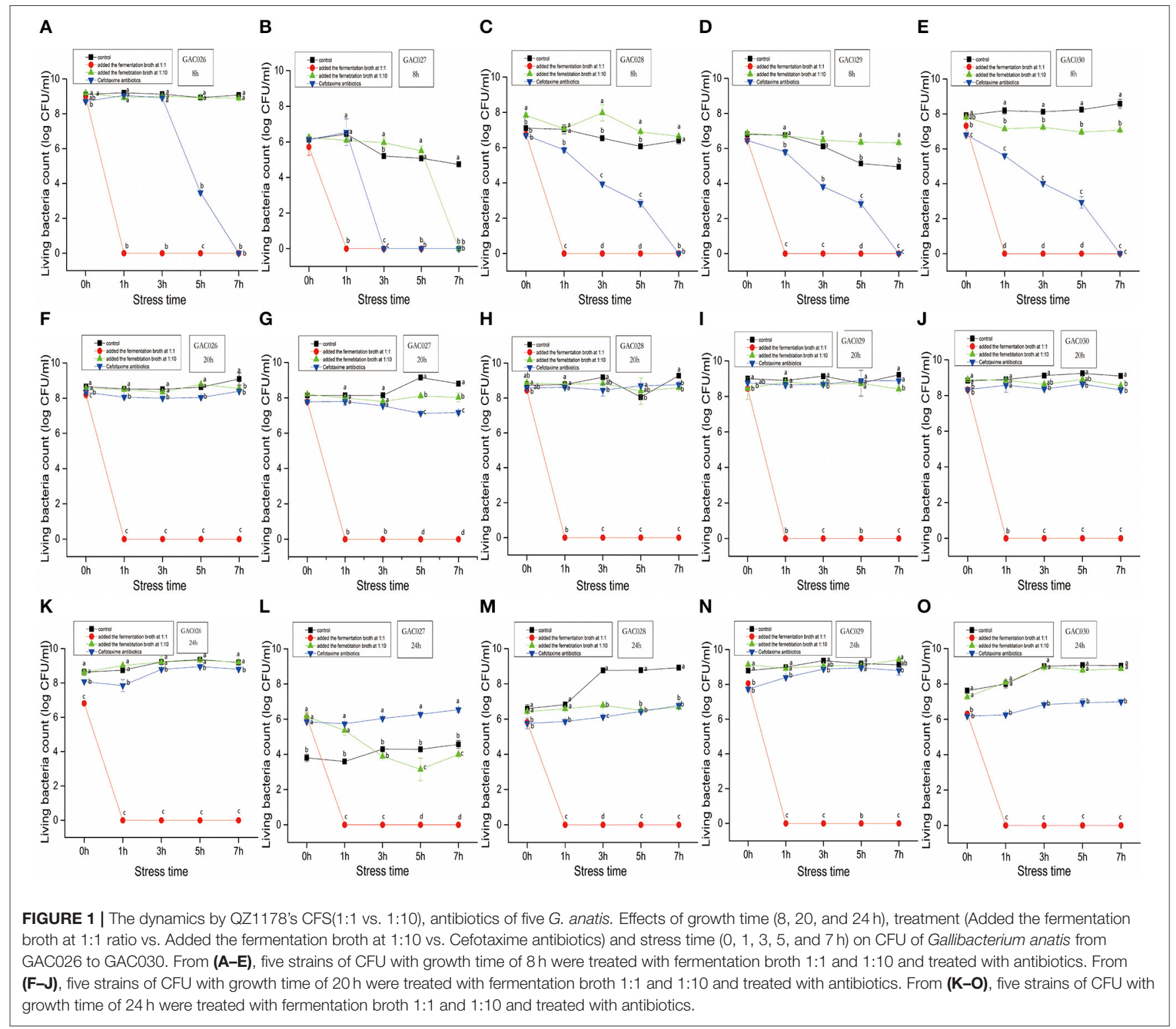

GAC105 was $>15 \mathrm{~mm}$, and the antibacterial diameters for nine strains were $15-20 \mathrm{~mm}$. Bacteriostasis for six strains was weak $(10-15 \mathrm{~mm})$.

\section{Organic Acid and pH Analysis of CFS}

According to HPLC data, the major organic acid in L. mesenteroides QZ1178 was LA, followed by AA; the concentrations for both reached 29 and $7 \mathrm{mg} / \mathrm{mL}$, respectively. PA and BA were not detected in L. mesenteroides QZ1178 CFS. The $\mathrm{pH}$ supernatant declined sharply and remained at $\mathrm{pH} 3.6$ after a $24 \mathrm{~h}$ incubation.

\section{OD Values of Cefotaxime Against Five G. anatis Strains (From GAC026 to GAC030)}

Table 2 showed the OD values of cefotaxime against five $G$. anatis strains (from GAC026 to GAC030). Like other cephalosporins, cefotaxime is a wide spectrum antibiotic that inhibits the growth of both Gram-negative and Gram-Positive bacteria. Of the tested strains, GAC026 and GAC027 were more sensitive to cefotaxime, whereas GAC028, GAC029, and GAC030 exhibited moderate sensitivity. Increased cefotaxime concentrations led to a marked decrease in G. anatis strains viabilily (Table 2 ). The MIC values for $G$. anatis $\mathrm{GAC} 026$ was $2.5 \mu \mathrm{g} / \mathrm{mL}$ when the absorbance was 0.09 at $600 \mathrm{~nm}$, whereas, its viability increased after exposure to $1.25 \mu \mathrm{g} / \mathrm{mL}$ cefotaxime, i.e., the OD was 0.27 . Thus, cefotaxime exhibited reasonable antibactericidal activity.

\section{Leuconostoc mesenteroides QZ1178's CFS and Cefotaxime Inhibited G. anatis (GAC026-GAC030) Growth}

The characteristics of five $G$. anatis strains treated by $L$. mesenteroides QZ1178 CFS, antibiotics and control are shown (Figure 1). Most G. anatis strains formed biofilms, to different 
TABLE 3 | Effect of pH on the antagonistic activity of QZ1178's CFS by measuring inhibition zones ( $\mathrm{mm}$ ).

\begin{tabular}{lcc}
\hline pH & QZ1178's CFS & Lactic acid \\
\hline 4 & +++ & +++ \\
5 & ++ & +++ \\
5.5 & - & - \\
6 & - & -
\end{tabular}

The inhibition zone contains the external diameter of the cup. Diameter of inhibition zone: -, no inhibition; ++, 15-20 mm; + + +, 20-25 mm; $n=3$.

degrees. Initial cell adhesion commenced at $8 \mathrm{~h}$, more at $20 \mathrm{~h}$, with a complete biofilm formed at $24 \mathrm{~h}$. Therefore, 8,20 , and $24 \mathrm{~h}$ time points were selected as observation points. After adding a high dose of L. mesenteroides QZ1178 fermentation broth, the CFU values for $G$. anatis were significantly reduced $(P<0.05)$ when compared with controls. The CFU rapidly decreased to 0 at $1 \mathrm{~h}$ and was still 0 at $7 \mathrm{~h}$. By adding fermentation broth at a high dose, this significantly decreased $G$. anatis strain growth $(P<0.05)$. However, CFU values for $G$. anatis were not decreased after adding a low dose fermentation broth. Organic acids, including short chain fatty acids, LA and formic acid were previously shown to inhibit pathogens in livestock animals, with LA considered a main fermentation product of LAB (29). The highest inhibition rate (at 8,20 , and $24 \mathrm{~h}$ ) toward G. anatis was probably mediated by organic acids in the fermentation broth. At $8 \mathrm{~h}$, cefotaxime addition significantly $(P<0.05)$ reduced the CFU's of $G$. anatis when compared with controls, but no significant decrease was observed at 20 and $24 \mathrm{~h}$, suggesting antibiotic resistance had occurred.

\section{The Antagonistic Activity of $L$. mesenteroides QZ1178 CFS When Neutralized With Alkali}

Leuconostoc mesenteroides QZ1178 CFS was evaluated for antibacterial activity against $G$. anatis GAC026 after $\mathrm{pH}$ adjustment. The antibacterial activity of $L$. mesenteroides QZ1178 CFS and LA were both lessened at increased pHs. No antibacterial activity was observed at $\mathrm{pH} 5.5$ and 6.0, while the CFS of L. mesenteroides QZ1178 showed moderate antibacterial effects against G. anatis GAC026 at pH 4 and pH 5 (Table 3). These results suggested $\mathrm{LAB}$ mediated acid conditions played a critical role in the antagonistic activity of $L$. mesenteroides QZ1178 CFS.

\section{The Inhibition of G. anatis GAC026 Growth Using Different Organic Acids}

The effects of LA, AA, and HA on G. anatis growth are shown (Table 4). Adding LA, AA, and HA in 1:1 ratios, significantly decreased $G$. anatis GAC026 growth. LA and AA both significantly reduced the CFU for $G$. anatis GAC026 when compared with controls. G. anatis CFU decreased gradually after HA was added at 1:1, suggesting strong acids generated no significant inhibitory effects on G. anatis GAC026. Cell counts for $G$. anatis GAC026 treated with LA and AA decreased rapidly to $0 \mathrm{~h}$ at $1 \mathrm{~h}$, and continued for at least $7 \mathrm{~h}$. This phenomenon was not observed in $\mathrm{HA}+\mathrm{H}_{2} \mathrm{O}$ treated $\mathrm{G}$. anatis $\mathrm{GAC} 026$.

\section{The Effects of LA, Fermentation Broth, and Cefotaxime on Cell Morphology Using SEM} Gallibacterium anatis GAC026 cell morphological changes are shown (Figure 2). Untreated cells displayed typical bacilliform and spherical morphology, of uniform size (Figures 2A-E). The cell surface appeared intact and glossy. In contrast, cells treated with fermentation broth at a 1:1 ratio (Figures $2 \mathbf{K}-\mathbf{O}$ ) were irregular, had a wrinkled outer surface, extensive surface collapse, with increased cell damage. Cells treated with LA at $29 \mathrm{mg} / \mathrm{mL}$ (Figures 2P-T) showed some pores or localized ruptures in membranes. Intracellular material had leaked from membranes, and form aggregations and adhesions. With prolonged acid stress, GAC026 cells were severely damaged, and most membranes had collapsed and ruptured, generating debris. Such morphological alterations were previously observed for bacteria treated with organic acids (3). Cefotaxime treated G. anatis GAC026 cells showed altered cell surface morphology, surface shrinkage, and shrunken walls (Figures 2F-J).

\section{The Effects of LA, Fermentation Broth, and Cefotaxime on Cell Morphology Using TEM} Changes in cellular ultrastructure, with and without treatment, in G. anatis GAC026 cells were observed by TEM. For the control group, cells exhibited a clear, uniform cytoplasm at $0 \mathrm{~h}-7 \mathrm{~h}$ (Figures 3A-E), including intact DNA fibrils (Figures 3B-D; black arrows) and dividing cells (Figure 3E). However, upon fermentation broth addition for $1 \mathrm{~h}$, some $G$. anatis GAC026 membranes ruptured and cytoplasmic contents leaked (Figure 3K). A clear loss of cell envelope integrity was also observed (Figure 3L).

In general, morphological cell structures exposed to CFS remained unchanged, but membrane structural integrity was severely disrupted in a time-dependent manner. Most cells collapsed or lysed, resulting in death. Cell contents with no cell walls were observed (Figures 3M,N). G. anatis GAC026 was treated with fermentation broth for $7 \mathrm{~h}$ (Figure 3O). G. anatis GAC026 was treated with LA for $0 \mathrm{~h}$ (Figure 3P). After LA treatment for $1 \mathrm{~h}$, tightly condensed substances or dense granules contracted together (Figures 3Q-S). G. anatis GAC026 was treated with LA for $7 \mathrm{~h}$ (Figure 3T). Both fermentation broth and LA changed G. anatis GAC026 morphology, leading to cell membrane rupture, and incomplete or total whole cell membrane loss when compared with controls. G. anatis GAC026 morphology at $2.5 \mu \mathrm{g} / \mathrm{mL}$ cefotaxime changed from oblong to triangular or irregular shapes (Figures $3 \mathbf{F}-\mathbf{H}$ ). Large gaps between the capsule and cell wall (Figure $3 \mathbf{H}$ ), and cell wall atrophy or depression were also observed. However, cell contents did not leak (Figures 3I,J).

\section{DISCUSSION}

Gallibacterium anatis is a Gram-negative coccobacillus, and commensal inhabitant of the respiratory and reproductive tract 
TABLE 4 | Effects of different treatment on the growth of G. anatis.

\begin{tabular}{|c|c|c|c|c|c|c|c|}
\hline \multirow[t]{2}{*}{ Stress time } & \multicolumn{7}{|c|}{ Treatment } \\
\hline & $\begin{array}{c}\text { Control } \\
\text { (log CFU/ml) }\end{array}$ & $\begin{array}{c}\text { Lactic } \\
\text { acid } \\
\text { +MRS }\end{array}$ & $\begin{array}{l}\text { Lactic acid } \\
\qquad+\mathrm{H}_{2} \mathrm{O}\end{array}$ & $\begin{array}{c}\text { Acetic } \\
\text { acid } \\
\text { +MRS }\end{array}$ & $\begin{array}{l}\text { Acetic acid } \\
\quad+\mathrm{H}_{2} \mathrm{O}\end{array}$ & $\begin{array}{c}\text { HCL } \\
+ \text { MRS }\end{array}$ & $\begin{array}{c}\text { HCL } \\
+ \text { MRS }\end{array}$ \\
\hline $\mathrm{Oh}$ & $9.03 \pm 0.05^{\mathrm{Aa}}$ & $9.05 \pm 0.05^{\mathrm{Aa}}$ & $N D^{d}$ & $8.88 \pm 0.07^{A b}$ & $4.40 \pm 0.11^{\mathrm{Ac}}$ & $8.94 \pm 0.07^{A a b}$ & $8.94 \pm 0.04 \mathrm{Aab}$ \\
\hline $1 \mathrm{~h}$ & $9.07 \pm 0.15^{\mathrm{Aa}}$ & $N D^{B d}$ & $N D^{d}$ & $3.92 \pm 0.08^{\mathrm{Bc}}$ & $N D^{B d}$ & $3.96 \pm 0.16^{\mathrm{Bc}}$ & $8.79 \pm 0.03^{\mathrm{Bb}}$ \\
\hline $3 \mathrm{~h}$ & $8.84 \pm 0.06^{\mathrm{Ba}}$ & $\mathrm{ND}^{\mathrm{Bc}}$ & $N^{c}$ & $N D^{\mathrm{Cc}}$ & $N D^{\mathrm{Bc}}$ & $N D^{\mathrm{Cc}}$ & $8.51 \pm 0.06^{\mathrm{Cb}}$ \\
\hline $5 \mathrm{~h}$ & $8.78 \pm 0.02^{\mathrm{Ba}}$ & $\mathrm{ND}^{\mathrm{Bc}}$ & $\mathrm{ND}^{\mathrm{C}}$ & $\mathrm{ND}^{\mathrm{Cc}}$ & $\mathrm{ND}^{\mathrm{Bc}}$ & $\mathrm{ND}^{\mathrm{Cc}}$ & $6.53 \pm 0.09^{\mathrm{Db}}$ \\
\hline $7 \mathrm{~h}$ & $\begin{array}{l}9.00 \pm \\
0.13^{\mathrm{ABa}}\end{array}$ & $\mathrm{ND}^{\mathrm{Bc}}$ & $N^{c}$ & $\mathrm{ND}^{\mathrm{Cc}}$ & $\mathrm{ND}^{\mathrm{Bc}}$ & $\mathrm{ND}^{\mathrm{Cc}}$ & $3.93 \pm 0.06^{\mathrm{Eb}}$ \\
\hline
\end{tabular}

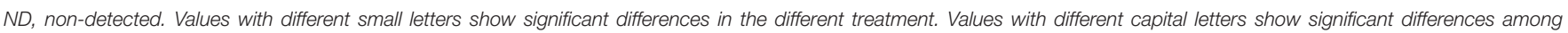
treatments in the stress time $(P<0.05)$.

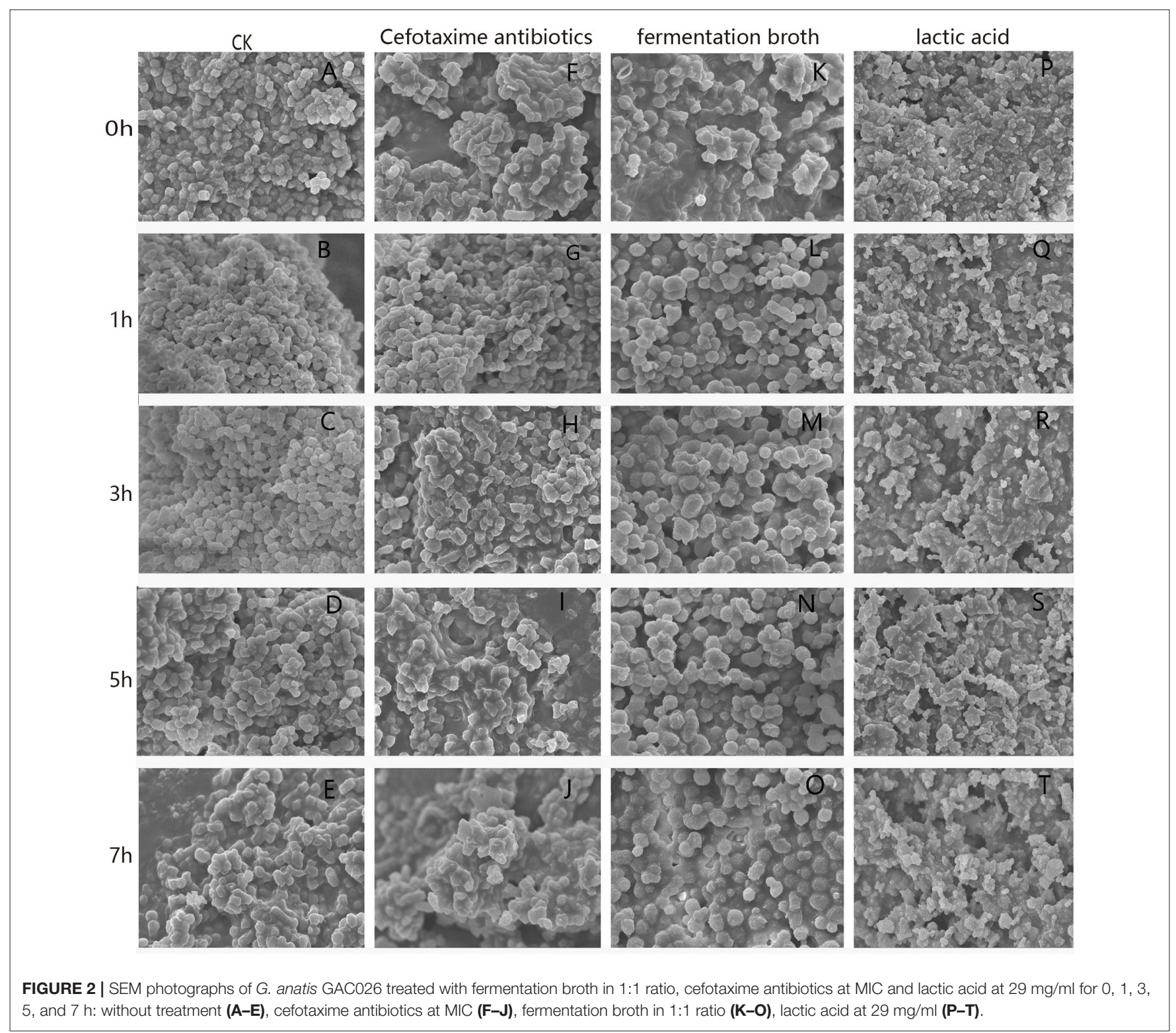




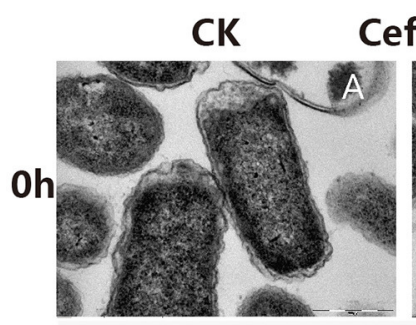

efotaxime antibiotics fermentation broth

\section{lactic acid}
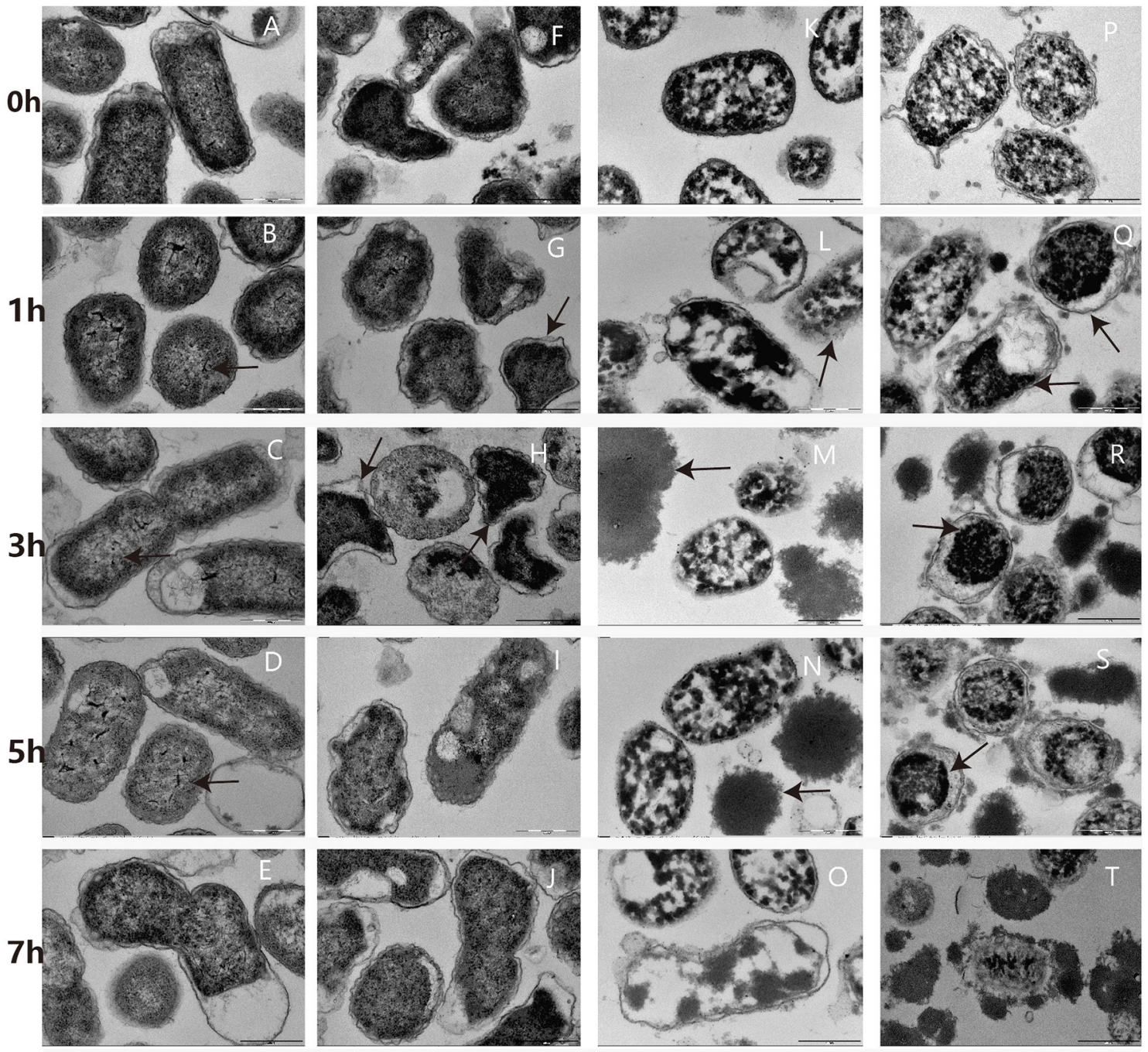

FIGURE 3 | TEM photographs of G. anatis GAC026 treated with fermentation broth in 1:1 ratio, cefotaxime antibiotics at MIC and lactic acid at 29 mg/ml for 0, 1,3 , 5, and 7 h: without treatment (A-E), cefotaxime antibiotics at MIC (F-J), fermentation broth in 1:1 ratio (K-0), lactic acid at 29 mg/ml (P-T). The DNA fibrils (arrows in B-D). The dividing cell (E). G. anatis GAC026 was treated with cefotaxime antibiotics for 0 h (F). Triangular or irregular G. anatis GAC026 (arrows in G, H). A big gap between the capsule and the cell wall (arrows in $\mathbf{H}$ ). G. anatis GAC026 was treated with cefotaxime antibiotics for $5 \mathrm{~h}$ (I) and $7 \mathrm{~h}$ (J). The cell envelope ruptured (arrows in L). Cells contents without cell walls (arrows in $\mathbf{M}, \mathbf{N}$ ). G. anatis GAC026 was treated with fementtation broth for $7 \mathrm{~h}$ (0). G. anatis GAC026 was treated with lactic acid for $0 \mathrm{~h}$ (P). The tightly condensed substances or dense granules contracted together (arrows in $\mathbf{Q}-\mathbf{S}$ ). $\mathbf{G}$. anatis $\mathbf{G A C 0 2 6}$ was treated with lactic acid for $7 \mathrm{~h}$ (T).

of birds. It is an opportunistic pathogen in intensively reared poultry and domestic birds, and has emerged as a multidrugresistant pathogen causing decreased egg production, salpingitis, peritonitis, and even respiratory tract lesions $(20,30,31)$.

Currently, antibiotics are used to treat G. anatis infections, however, antibiotic resistance to commonly used therapies, including penicillin, macrolides, and tetracyclines are major concerns, although the pathogen remains sensitive to certain novel antibiotics, e.g., cefotaxime. In agreement, G. anatis GAC026 was sensitive to cefotaxime in our study. At $8 \mathrm{~h}$, the antibiotic significantly reduced $G$. anatis when compared with controls, but no significant decreases were observed at 20 and $24 \mathrm{~h}$. Cefotaxime inhibits bacterial cell wall synthesis by competitively inhibiting transpeptidase.
Resistance against cefotaxime increased significantly with the time of growth of $G$. anatis GAC026. Using SEM, G. anatis GAC026 in $2.5 \mu \mathrm{g} / \mathrm{mL}$ cefotaxime changed from oblong to triangular or irregular shapes, suggesting cell wall atrophy or depression had occurred, however, cell contents did not leak.

Owing to the emergence of widespread multidrug resistance, traditional antimicrobial drugs are not indicated for this bacterial pathogen. The efficacy of classical vaccines in preventing this disease is limited due to disease antigenic diversity (32). Common G. anatis virulence factors include the capsule, outer membrane vesicles, fimbriae, metalloproteases, and biofilm formation, etc. (33-35). Thus, a major problem in combating G. anatis is multidrug resistance. For Gram-negative bacteria, typical antimicrobial agents only generate bacteriostatic or 
bactericidal effects upon cell entry. Outer membranes are composed of asymmetric phospholipid and lipopolysaccharide layers $(36,37)$. This latter layer forms a tight barrier limiting compound access, including antibiotics (38-40). Additionally, lipopolysaccharide core regions coordinate divalent cations, including $\mathrm{Fe}^{2+}, \mathrm{Mg}^{2+}$, and $\mathrm{Ca}^{2+}$ (41). If such cations are removed, lipopolysaccharide molecules are released from outer membranes, exposing underlying phospholipid bilayers, and disrupting outer membrane integrity. Organic acids appear to have unique mechanisms which differ with antibiotics.

Protonated organic acid molecules diffuse directly through cell membranes or pore proteins, to release protons and anions and inhibit cell growth $(42,43)$. Weak organic acids, such as LA, are more effective than inorganic acids in killing bacteria (44). LABs exert antimicrobial activities by secreting LA, which effectively kill both Gram-negative and Gram-positive pathogens (45). These molecules lower the surrounding $\mathrm{pH}$ which stresses cells. Equally, protonated LAs permeabilize cell membranes and enter the cytoplasm, where they dissociate and lower the internal $\mathrm{pH}$ (Gallmann, 2003). Theoretically, undissociated elements of acid molecules are primarily responsible for antimicrobial activity, while their effectiveness at a given $\mathrm{pH}$ depends to a large extent on the dissociation constant ( $\mathrm{pKa}$ ) of the acid. However, fully dissociated "strong" acids (e.g., $\mathrm{HCl}$ ) do not contain undissociated elements of the acid molecule, and "strong" acids can only affect bacterial cells by changing the $\mathrm{pH}$ (proton concentration) (46). As observed here, LA was more effective than strong acids like $\mathrm{HCl}$ in inhibiting $\mathrm{G}$. anatis growth at $\mathrm{pH} 3.6$, due to its dissociation and unique pKa. Our TEM data suggested that exposure to 1:1 ratios of fermentation broth and LA of the same concentration, inhibited $G$. anatis growth via cell membrane destruction. Thus, our study extends the knowledge on soluble metabolites responsible for CFS effects from LAB. We showed that acidic supernatants at pH 5.5 displayed no inhibitory activities against pathogenic bacteria, suggesting any inhibitory effects were probably due to organic acids such as LA.

LAB can modify host gastrointestinal microbiota, and prevent respiratory and genitourinary infections (47). This study only

\section{REFERENCES}

1. Kecerová K, Pristaš P, Javorský P. Bacteriocin production and sensitivity. Folia Microbiol. (2004) 49:172-4. doi: 10.1007/BF02931395

2. Bilkova A, Kinova Sepova H, Bukovsky M, Bezakova L. Antibacterial potential of lactobacilli isolated from a lamb. Vet Med-Czech. (2011) 56:31924. doi: 10.17221/1583-VETMED

3. Alakomi HL, Skytta E, Saarela M, Mattila-Sandholm T, LatvaKala K, et al. Lactic acid permeabilizes Gram-negative bacteria by disrupting the outer membrane. Appl Environ Microbiol. (2000) 66:2001-5. doi: 10.1128/AEM.66.5.2001-2005.2000

4. Ricke SC. Perspectives on the use of organic acids and short chain fatty acids as antimicrobials. Poult Sci. (2003) 82:632-9. doi: 10.1093/ps/ 82.4 .632

5. Maurer LM, Yohannes E, Bondurant SS, Radmacher M, Slonczewski JL. pH regulates genes for flagellar motility, catabolism, and oxidative stress in Escherichia coli K-12. J Bacteriol. (2005) 187:304-19. doi: 10.1128/JB.187.1.304-319.2005 confirmed the in vitro antibacterial effect of $L$. mesenteroides QZ1178 by generating the acid microenvironment. Further research is required to assess whether L. mesenteroides QZ1178 or its metabolites interact with the immune system to enhance defense capabilities against systematic or local infections.

\section{CONCLUSIONS}

We compared changes in $G$. anatis treated with $L$. mesenteroides QZ1178 CFS, cefotaxime, and LA. G. anatis growth was significantly inhibited after a 1:1 ratio of fermentation broth was added to cells, whose effect was compromised when the acid was neutralized. From our in vitro work, we concluded L. mesenteroides QZ1178 was a probiotic which may inhibit bird gut microbiota pathogens via LA generation.

\section{DATA AVAILABILITY STATEMENT}

The original contributions presented in the study are included in the article/supplementary material, further inquiries can be directed to the corresponding author/s.

\section{AUTHOR CONTRIBUTIONS}

HZ, HH, XW, SZ, YL, HL, and GQ designed and did experiments. ZT superivised the project. $\mathrm{HZ}$ drafted and finalized the manuscript. All authors contributed to the article and approved the submitted version.

\section{FUNDING}

This work was supported by the National Natural Science Foundation of China (No. 31772672), Foundation of Key Technology Research Project of Henan Province (Grant No. 182102110090 and Grant No. 192102110082) and Major collaborative innovation project of Zhengzhou (Key discipline construction project of Zhengzhou University) (No. xkzdjc201905).
6. Neal-McKinney JM, Lu X, Duong T, Larson CL, Call DR, Shah $\mathrm{DH}$, et al. Production of organic acids by probiotic lactobacilli can be used to reduce pathogen load in poultry. PLoS ONE. (2012) 7:e43928. doi: 10.1371/journal.pone.0043928

7. Tejero-Sariñena S, Barlow J, Costabile A, Gibson GR, Rowland I. In vitro evaluation of the antimicrobial activity of a range of probiotics against pathogens: evidence for the effects of organic acids. Anaerobe. (2012) 18:5308. doi: 10.1016/j.anaerobe.2012.08.004

8. Rodríguez-Pazo N, Vázquez-Araújo L, Pérez-Rodríguez N, Cortés-Diéguez S, Domínguez JM. Cell-free supernatants obtained from fermentation of cheese whey hydrolyzates and phenylpyruvic acid by Lactobacillus plantarum as a source of antimicrobial compounds, bacteriocins, natural aromas. Appl Biochem Biotechnol. (2013) 171:1042-60. doi: 10.1007/s12010-013-0408-7

9. Oguntoyinbo FA, Narbad A. Multifunctional properties of Lactobacillus plantarum strains isolated from fermented cereal foods. J Funct. Foods. (2015) 17:621-31. doi: 10.1016/j.jff.2015.06.022

10. Samot J, Badet C. Antibacterial activity of probiotic candidates for oral health. Anaerobe. (2013) 19:34-8. doi: 10.1016/j.anaerobe.2012.11.007 
11. Vieira AT, Teixeira MM, Martins FS. The role of probiotics and prebiotics in inducing gut immunity. Front Immunol. (2013) 4:445. doi: 10.3389/fimmu.2013.00445

12. Cortes-Zavaleta O, Lopez-Malo A, Hernandez-Mendoza A, Garcia HS. Antifungal activity of lactobacilli and its relationship with 3-phenyllactic acid production. Int J Food Microbiol. (2014) 173:30-5. doi: 10.1016/j.ijfoodmicro.2013.12.016

13. McFarland LV. Use of probiotics to correct dysbiosis of normal microbiota following disease or disruptive events: a systematic review. BMJ Open. (2014) 4:e005047. doi: 10.1136/bmjopen-2014-005047

14. Maldonado GC. Stimulation of innate immune cells induced by probiotics: participation of toll-like receptors. J Clin Immunol. (2015) 6:283. doi: 10.4172/2155-9899.1000283

15. Zhang B, Wang YP, Tan ZF, Li ZW, Jiao Z, Huang QC. Screening of probiotic activities of Lactobacilli strains isolated from traditional Tibetan Qula, a raw yak milk cheese. Asian-Australasian J. Anim. Sci. (2016) 29:14909. doi: 10.5713/ajas.15.0849

16. Bojesen AM, Torpdahl M, Christensen H, Olsen JE, Bisgaard M. Genetic diversity of Gallibacterium anatis isolates from different chicken flocks. J Clin Microbiol. (2003) 41:2737-40. doi: 10.1128/JCM.41.6.2737-2740.2003

17. Bisgaard M, Korczak BM, Busse HJ, Kuhnert P, Bojesen AM, Christensen H. Classification of the taxon 2 and taxon 3 complex of Bisgaard within Gallibacterium and description of Gallibacterium melopsittaci sp. nov., Gallibacterium trehalosifermentans sp. nov. and Gallibacterium salpingitidis sp. nov. Int J Syst Evol Microbiol. (2009) 59(Pt 4):73544. doi: 10.1099/ijs.0.005694-0

18. Christensen H, Bisgaard M, Bojesen AM, Mutters R, Olsen JE. Genetic relationships among avian isolates classified as Pasteurella haemolytica, 'Actinobacillus salpingitidis' or Pasteurella anatis with proposal of Gallibacterium anatis gen. nov., comb. nov. and description of additional genomospecies within Gallibacterium gen. nov. Int J Syst Evol Microbiol. (2003) 53(Pt 1):275-87. doi: 10.1099/ijs.0.02330-0

19. Jordan FTW, Williams NJ, Wattret A, Jones,T. Observations on salpingitis, peritonitis and salpingoperitonitis in a layer breeder flock. Vet Rec. (2005) 157:573-7. doi: 10.1136/vr.157.19.573

20. Paudel S, Liebhart D, Hess M, Hess C. Pathogenesis of Gallibacterium anatis in a natural infection model fulfils Koch's postulates: 1. Folliculitis and drop in egg production are the predominant effects in specific pathogen free layers. Avian Pathol. (2014) 43:443-9. doi: 10.1080/03079457.2014. 955782

21. Aubin GG, Haloun A, Treilhaud M, Reynaud A, Corvec S. Gallibacterium anatis bacteremia in a human. J Clin Microbiol. (2013) 51:3897-9. doi: 10.1128/JCM.01638-13

22. El-Adawy H, Bocklisch H, Neubauer H, Hafez HM, Hotzel H. Identification, differentiation and antibiotic susceptibility of Gallibacterium isolates from diseased poultry. Ir Vet J. (2018) 71:5. doi: 10.1186/s13620-0180116-2

23. Elbestawy AR, Ellakany HF, Abd El-Hamid HS, Bekheet AA, Mataried NE, Nasr SM, et al. Isolation, characterization, and antibiotic sensitivity assessment of Gallibacterium anatis biovar haemolytica, from diseased Egyptian chicken flocks during the years 2013 and 2015. Poult Sci. (2018) 97:1519-25. doi: 10.3382/ps/pey007

24. Bajpai VK, Rather IA, Majumder R. Characterization and antibacterial mode of action of lactic acid bacterium Leuconostoc mesenteroides HJ69 from Kimchi. J Food Biochem. (2017) 41:e12290. doi: 10.1111/jfbc. 12290

25. Zoumpopoulou G, Papadimitriou K, Alexandraki V, Mavrogonatou E, Alexopoulou K, Anastasiou R, et al. The microbiota of Kalathaki and Melichloro Greek artisanal cheeses comprises functional lactic acid bacteria. LWT-Food Sci Technol. (2020) 130:109570. doi: 10.1016/j.lwt.2020. 109570

26. Huangfu HP, Xu WB, Wang HK, Dong Q, Guo HW, Sun YT, et al. Detection of Gallibacterium anatis by TaqMan fluorescent quantitative PCR. Avian Pathol. (2018) 47:245-52. doi: 10.1080/03079457.2017.1416590

27. Castilho NPA, Colombo M, Oliveira LL, Todorov SD, Nero LA. Lactobacillus curvatus UFV-NPAC1 and other lactic acid bacteria isolated from calabresa, a fermented meat product, present high bacteriocinogenic activity against Listeria monocytogenes. BMC Microbiol.

(2019) 19:63. doi: 10.1186/s12866-019-1436-4

28. Sieniawska E, Swatko-Ossor M, Sawicki R, Skalicka-Wozniak K, Ginalska G. Natural terpenes influence the activity of antibiotics against isolated Mycobacterium tuberculosis. Med Prin Pract. (2017) 26:108-12. doi: 10.1159/000454680

29. Russo P, Arena MP, Fiocco D, Capozzi V, Drider D, Spano G. Lactobacillus plantarum with broad antifungal activity: a promising approach to increase safety and shelf-life of cereal-based products. Int J Food Microbiol. (2017) 247:48-54. doi: 10.1016/j.ijfoodmicro.2016.04.027

30. Mushin R, Weisman Y, Singer N. Pasteurella haemolytica found in the respiratory tract of fowl. Avian Dis. (1980) 24:162-8. doi: 10.2307/1589775

31. Persson G, Bojesen AM. Bacterial determinants of importance in the virulence of Gallibacterium anatis in poultry. Vet Res. (2015) 46:57. doi: 10.1186/s13567-015-0206-Z

32. Krishnegowda DN, Dhama K, Mariappan,A. K., Munuswamy P. Yatoo MI, et al. Etiology, epidemiology, pathology, and advances in diagnosis, vaccine development, and treatment of Gallibacterium anatis infection in poultry: a review. Vet Quart. (2020) 40:16-34. doi: 10.1080/01652176.2020. 1712495

33. Miyoshi SI, Shinoda S. Microbial metalloproteases and pathogenesis. Microbes Infect. (2000) 2:91-8. doi: 10.1016/S1286-4579(00)00280-X

34. Bager RJ, Nesta B, Pors SE, Soriani M, Serino L, Boyce JD, et al. The fimbrial protein FlfA from Gallibacterium anatis is a virulence factor and vaccine candidate. Infect Immun. (2013) 81:1964-73. doi: 10.1128/IAI.00059-13

35. Bager RJ, Persson G, Nesta B, Soriani M, Serino L, Jeppsson M, et al. Outer membrane vesicles reflect environmental cues in Gallibacterium anatis. Vet Microbiol. (2013) 167:565-72. doi: 10.1016/j.vetmic.2013.09.005

36. Koebnik R, Locher KP, Van Gelder. P. Structure and function of bacterial outer membrane proteins: barrels in a nutshell. Mol Microbiol. (2000) 37:23953. doi: 10.1046/j.1365-2958.2000.01983.x

37. Sondhi P, Maruf MHU, Stine KJ. Nanomaterials for biosensing lipopolysaccharide. Biosensors-Basel. (2019) 10:2. doi: 10.3390/bios10010002

38. Zgurskaya HI, Lopez CA, Gnanakaran S. Permeability barrier of gramnegative cell envelopes and approaches to bypass it. ACS Infect. Dis. (2015) 1:512-2. doi: 10.1021/acsinfecdis.5b00097

39. Brown DG. Drug discovery strategies to outer membrane targets in Gram-negative pathogens. Bioorgan Med Chem. (2016) 24:6320-31. doi: 10.1016/j.bmc.2016.05.004

40. Zabawa TP, Pucci MJ, Parr TR, Lister T. Treatment of Gram-negative bacterial infections by potentiation of antibiotics. Curr Opin Microbiol. (2016) 33:712. doi: 10.1016/j.mib.2016.05.005

41. Langley S, Beveridge TJ. Effect of O-side-chain-lipopolysaccharide chemistry on metal binding. Appl Environ Microbiol. (1999) 65:489-98. doi: 10.1128/AEM.65.2.489-498.1999

42. Lues JF, Theron MM. Comparing organic acids and salt derivatives as antimicrobials against selected poultry-borne Listeria monocytogenes strains in vitro. Foodborne Pathog Dis. (2012) 9:1126-9. doi: 10.1089/fpd.20 12.1220

43. Borges A, Ferreira C, Saavedra MJ, Simoes M. Antibacterial activity and mode of action of ferulic and gallic acids against pathogenic bacteria. Microb Drug Resist. (2013) 19:256-65. doi: 10.1089/mdr.2012.0244

44. Wang CJ, Chang T, Yang H, Cui M. Surface physiological changes induced by lactic acid on pathogens in consideration of pKa and pH. Food Control. (2014) 46:525-31. doi: 10.1016/j.foodcont.2014.06.024

45. Atassi F, Ahn DL, Moal PV. Diverse expression of antimicrobial activities against bacterial vaginosis and urinary tract infection pathogens by cervicovaginal microbiota strains of Lactobacillus gasseri and Lactobacillus crispatus. Front Microbiol. (2019) 10:2900. doi: 10.3389/fmicb.2019. 02900

46. Tashiro Y, Ichikawa S, Shimizu M, Toyofuku M, Takaya N, NakajimaKambe T, et al. Variation of physiochemical properties and cell association activity of membrane vesicles with growth phase in Pseudomonas aeruginosa. Appl Environ Microbiol. (2010) 76:3732-9. doi: 10.1128/AEM. 02794-09

47. Nader-Macías MEF, Alvarez GS, Ruiz CS, Medina M, Silvina M, et al. Lactic acid bacteria in the prevention of urogenital and respiratory 
infections. In: Mozzi F, Vignolo RR, editors. Biotechnology of Lactic Acid Bacteria: Novel Applications. Ames, IA: Wiley-Blackwell (2010).p. 14159. doi: $10.1002 / 9780813820866 . c h 8$

Conflict of Interest: The authors declare that the research was conducted in the absence of any commercial or financial relationships that could be construed as a potential conflict of interest.
Copyright (c) 2021 Zhang, HuangFu, Wang, Zhao, Liu, Lv, Qin and Tan. This is an open-access article distributed under the terms of the Creative Commons Attribution License (CC BY). The use, distribution or reproduction in other forums is permitted, provided the original author(s) and the copyright owner(s) are credited and that the original publication in this journal is cited, in accordance with accepted academic practice. No use, distribution or reproduction is permitted which does not comply with these terms. 